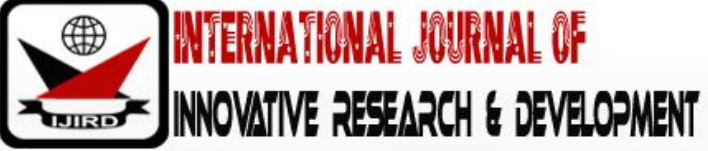

ISSN 2278 - 0211 (Online)

\section{Relationship between Practical Learning and Students' Performance in Information and Communications Technology}

\begin{tabular}{|c|} 
Benjamin Baiden \\
ICT Tutor, Department of Mathematics and ICT, St. Joseph's College of Education, Ghana \\
Victor King Anyanful \\
ICT Tutor, Department of Mathematics and ICT, OLA College of Education, Ghana \\
Victor Dannyansah \\
ICT Tutor, Department of Mathematics and ICT, Atebubu College of Education, Ghana \\
Bryce Yaw Kesse \\
ICT Tutor, Department of Mathematics and ICT, Berekum College of Education, Ghana
\end{tabular}

\begin{abstract}
:
Female student teachers who are the hope of the society cannot be neglected in this information age. One feels dejected to see level two hundred (200) female students of St. Joseph's and Berekum Colleges of Education not involving themselves in the practical activities in ICT. These students only show interest in the theory aspect of the subject (ICT), but the ICT syllabus for Colleges of Education aims at offering basic knowledge and skills to students (Ministry of Education Science and Sports, 2004). It is against this background that this research was conducted to ensure female students involve themselves and use ICT tools well in practical lessons. The researchers made use of quantitative research methodology together with random and stratified sampling techniques to collect valid data on the problem. Notwithstanding, questionnaire methodology was employed in gathering relevant data from the research population. Results from the study revealed that students reported certain things teachers do to reduce their interest in class. Teachers also reported that they deliver lessons without appropriate TLMs. Based on the findings; it was recommended that students should be given career guidance and counseling on the relevance of the subject through career conferences and conventions. In doing this, role models should be used. It was also recommended that school authorities must ensure provision of adequate ICT tools to facilitate the teaching and learning of ICT. They should also adopt monitoring system on teachers' effective use of the ICT tools.
\end{abstract}

Keywords: Practical learning, information and communication technology, female education, motivation, students' performance

\section{Introduction}

The teacher acts as a specialist who is guiding pupils (Duffy \& Bednar, 1991). Gallagher (1995) stated that using the computer made their work more attention-grabbing and effective. Schofield (1995) stated that the most frequently shared theme among studies of the impact of classroom computer use on teacher's roles was that in one way or the other classroom became less teacher-centered. In fact, using ICT can encourage a more student-oriented approach. However, the traditional chalk and talk method is a more teacher-centered approach. Pisapia (1994) concluded from a study of the use of ICT by educators, that teacher-centered teachers tended to use traditional instructional methods. Yet one of the conclusions of a study by a Dutch advisory committee for the Ministry of Education was that most of the current ICT applications were used to facilitate teacher-centered arrangements of learning process (COMMITT, 1996). Thus, ICT was often used to complement rather than authors stress the influence of existing classroom routines.

The incorporation of ICT in Ghanaian school systems is a major step in promoting innovation. However, the educational system currently is faced with myriads of setbacks including lack of adequate computers and other ICT tools especially in rural schools, poor internet connections, inadequate manpower and lack of consistent ICT policy framework. The improvement of female students' use of ICT tools in Ghanaian school systems with particular reference to St. Joseph's and Berekum Colleges of Education is a bold stride in enhancing innovation. Nevertheless, the current educational system is confronted with myriads of constraints comprising lack of adequate computers and other ICT tools especially in rural schools, poor internet connections, insufficient manpower and lack of reliable and consistent ICT policy framework.

\subsection{Research Question}

The research question used for this study is as follows:

- Is there a relationship between practical learning and performance of students? 


\subsection{Reviewed Materials and Methods}

\subsubsection{Relationship between Practical Learning and Students' Performance}

Many Ghanaian teachers think that the core of educational system in Ghana is purely theoretical and therefore see no need to waste time to take learners through practical activities even when it becomes necessary. This is normally seen during assessment of students. After students have been taught practically, teachers design assessment modes theoretically. However, the researchers saw that effective use of practical activities in ICT courses would contribute to improving academic performance of students.

The impact of practical activities in teaching and learning is summed up in the old Chinese proverb which says "I hear and I forget. I see and I remember. I do and I understand".

Sarfo (2009) gave two definitions of practical.

- Definition 1: "Practical refers to a class or examination that requires participation in an activity such as an experiment or a medical procedure".

- Definition 2: "Practical concerns with actual facts and real life and experience, not theory".

Sarfo (2009) further stated that "practical method is good at managing matters and dealing with problems and difficulties".

Education, training and skills development are critical for women who want to enhance their career potential through the use of ICTs within as well as outside the ICT sector. Learning practices (learning through practice from the classroom to the workplace to the high-technology office and other forms of learning through remembering and activity) should be extended to girls (and women), made gender sensitive (women-specific training, ongoing user support, and mentoring in the communities where women live) and deepened for women as not only users but technicians, programmers, ICT policy-makers and advocates.

Sarfo (2009) defines practise or practice as the "act of rehearsing behaviour over and over, or engaging in an activity again and again, for the purpose of improving or mastering it, as in the phrase "practice makes perfect" It is a method of learning and of acquiring experience". The definition above indicates that learners should be taken through activities repeatedly to build their perfection in such activities. For instance, sports team practice to prepare for actual games. Playing a musical instrument well takes a lot of practice.

Observations in the classes confirm that the use of computers with the tools in an open setting has a mediating role for students' construction of knowledge (Fuglestad, 2005). Seeing the impact of practical activities in the classroom, Neeam and Hill (1987) confirm that the "implicit in these ideas is that learning is an active, not a passive process". Practical activity in the classroom is usually the best way to ensure active learning in the teaching-learning process. Students are thus given the opportunity to have firsthand experience on the skills being learnt.

The foregoing literature indicates that the impact of practical activities on teaching learning process cannot be underestimated. The researchers are therefore hopeful that incorporating practice into the "traditional" form of education will help learners to improve upon their academic performance. Nevertheless, the literature reviewed on the above subject is silent on how higher education should go hand in hand with the practical assessment as per the adequate improvement and performance on all manner of learners. Accordingly, Nuldén (1998) argues that higher education is supposed to be deep in the definition itself. The constructivism and the models of collaborations offer guidelines on how to organize education activities (practical and demonstration). However, in a tertiary course curriculum is knowledge goals expressed for the course.

Those knowledge goals should be reached by the student to pass the course. The goal guides the teacher for how he/ she shall plan the teaching and assessment in the course (Garrison \& Anderson, 2003; Greer, 2001). Greer (2001) argues that the students take an approach to their learning in relation to what is expected of them which has a relation on students' performance. Students' performance in practical assessment activity can be influenced by different variables (Dutton \&Dutton, 2002). One variable is the form of the course as either an online course or a campus course. Those two contexts include students with different social situations. Online students tend to be working (Nätuniversitet, 2005) or active with other duties beside of the studies. Dutton and Dutton (2002) show that online students can perform better than on-campus students but there are more drop outs in online courses. However, work besides the studies can have a negative effect on the results, work at home with the course can give better results, age of the student has little influence on students' performance and this is missing in the literature reviewed.

The examination is the most powerful tool the teacher has to promote a good teaching process. If we teach the students what to learn practically, we stimulate their wish to pass the examination. If we learn how we teach, we can stimulate the wish to ask questions, to learn more, the knowledge comes automatic (Nulden, 1998).

What is more, no mention was made by the earlier researchers on them term "student engagement" in practical activities which the recent researchers want to unfold below.

Student engagement has been defined as "participation in educationally effective practices, both inside and outside the classroom, which leads to a range of measurable outcomes" (Kuh, 2007), and as "the extent to which students are engaging in activities that higher education research has shown to be linked with high-quality learning outcomes" (Krause \& Coates, 2008). Similarly, Hu and Kuh (2001) define engagement as "the quality of effort students themselves devote to educationally purposeful activities that contribute directly to desired outcomes". By way of contrast, others have defined engagement as "the process whereby institutions and sector bodies make deliberate attempts to involve and empower students in the process of shaping the learning experience" (HEFCE, 2008). Combining these two perspectives, Kuh (2009) has defined student engagement as "the time and effort students devote to activities that are empirically 
linked to desired outcomes of college and what institutions do to induce students to participate in these activities (Kuh, 2009).

Coates (2007) on the other hand describes engagement as "a broad construct intended to encompass salient academic as well as certain non-academic aspects of the student experience", comprising the following:

- Active and collaborative learning;

- Participation in challenging academic activities;

- Formative communication with academic staff;

- Involvement in enriching educational experiences;

- Feeling legitimated and supported by university learning communities

Our understanding of the term 'student engagement', based on definitions in the literature and the discussion of the character of engagement and its alternatives, Kuh (2003) summarized below, is as follows:

Student engagement is concerned with the interaction between the time, effort and other relevant resources invested by both students and their institutions intended to optimize the student experience and enhance the learning outcomes and development of students and the performance, and reputation of the institution. The term 'student engagement' has its historic roots in a body of work concerned with student involvement, enjoying widespread currency particularly in North America and Australasia, where it has been firmly entrenched through annual large-scale national surveys While 'student engagement' has enjoyed considerable attention in the literature since the mid-1990s, its beginnings can substantively be seen a decade previously, seminally in Alexander Astin's work on student involvement (Astin, 1984). Following on from 'the student experience' and 'research-led teaching' before it, 'student engagement' has become the latest focus of attention among those aiming to enhance learning and teaching in higher education, headlining meeting agenda and theming conferences in campuses around the world. It is not difficult to understand why: a sound body of literature has established robust correlations between student involvement in a subset of 'educationally purposive activities', and positive outcomes of student success and development, including satisfaction, persistence, academic achievement and social engagement (Astin, 1984, 1993; Berger \&Milem, 1999).

In seeking to understand what is meant by 'engagement', some authors have considered its antithesis - if a student is not engaged, then what are they?

Mann (2001, p7) contrasted engagement with alienation, proposing the engagement-alienation dyad as a more useful framework to understand students' relationships to their learning than the surface-strategic-deep triad (Marton\&Säljö, 1976), since both 'surface' and 'strategic' approaches to learning are responses to alienation from the content and the process of study. Krause (2005) lists "inertia, apathy, disillusionment or engagement in other pursuits" as alternatives to engagement for the student. Krause describes this as follows:

Physicists use the term 'inertia' to describe the tendency of matter to retain its state of rest or of uniform motion in a straight line. In the case of some students ... inertia is a germane term to describe their attitude to university and their role in it. In this context I favour the term 'inertia' over disengagement. The latter suggests an active detachment or separation, whereas the former is more suggestive of doing nothing, which aptly depicts the state of being for a group of students who do not actively pursue opportunities to engage in their learning community. As well as the active, positive understanding of engagement typically found in the literature, Krause (2005) identifies two other interpretations of the concept.

The first of these is the use of analogous to 'appointment', as in the phrase "I have an engagement at two o'clock tomorrow afternoon", suggesting that engagement with their studies was simply something to slot into their calendars. The second connotation was less neutral: For some students, engagement with the university experience is like engaging in a battle, a conflict. These are the students for whom the culture of the university is foreign and at times alienating and uninviting. This view of a 'dark', hostile form of engagement stands in contrast to Mann's view of alienation as the diametric opposite of engagement, a conceptual conflict that we resolve through separating the passive response to alienation ('withdrawal', or 'apathy') from the active ('conflict'), which is itself a form of engagement.

\subsection{Empirical Basis of the Study}

Empirical basis of a research work can be defined as "research based on experimentation or observation. The word empirical means information gained by experience, observation, or experiment. The central theme in scientific method is that all evidence must be empirical which means it is based on evidence. In scientific method the word "empirical" refers to the use of working hypothesis that can be tested using observation and experiment. Empirical basis or evidence is information that justifies a belief in the truth or falsity of an empirical claim. In the empiricist view, one can only claim to have knowledge when one has a true belief based on empirical evidence. In addition, an empirical basis of a research work is a way of gaining knowledge by means of direct and indirect observation or experience. Empirical evidence (the record of one's direct observations or experiences) can be analyzed quantitatively or qualitatively. Through quantifying the evidence or making sense of it in qualitative form, a researcher can answer empirical questions, which should be clearly defined and answerable with the evidence collected (usually called data).

Research design varies by field and by the question being investigated. Many researchers combine qualitative and quantitative forms of analysis to better answer questions which cannot be studied in laboratory settings, particularly in the social sciences and in education. Uniquely, empirical basis of a research work has important objectives as follows:

- Goes beyond simply reporting observations.

- Promotes environment for improved understanding.

- Combines extensive research with detailed case study.

- Proves relevancy of theory by working in a real-world environment (context). 
Arguably, some of the reasons by which empirical research methods can be used are as follows:

- Traditional or superstitious knowledge has been trusted for too long.

- Empirical Research methods help integrating research and practice.

- Educational process or Instructional science needs to progress.

Moreover, the use of empirical basis or support in a research work/ study has the following advantages.

- Understands and responds more appropriately to dynamics of situations.

- Provides respect to contextual differences.

- Helps to build upon what is already known.

- Provides opportunity to meet standards of professional research.

In effect, the collection of evidence to prove or counter any theory involves planned research designs in order to collect empirical data. Several types of designs have been suggested and used by researchers. Also, accurate analysis of data using standard statistical methods remains critical in order to determine legitimacy of empirical research.

Literature review on previous studies or research related to this study have been discussed under the following headings; employing motivation to sustain female students' participation in practical lessons of ICT and exploration of factors that motivate female students in acquiring practical skills.

\subsection{Using Motivation to Sustain Female Students' Participation in ICT Practical Lessons}

Accordingly, Berliner (2008) is of the view that attribution theory describes the role of motivation in a person's success or failure in school situations. Success on a test, for instance, could be attributed to luck or hard work; the theory predicts the behavior of students depending on their responses.

Students' motivation has been the concern of many educationists and educational psychologists. Motivating female students to become active participants in the classroom practical activities is believed to contribute toward achieving the aim of this research study.

According to Becta (2008), research study on the motivational effect of ICT showed that, 'both teachers and pupils believe ICT can motivate both boys and girls, albeit in different ways and to varying extents'. This lends credence to the fact that motivating females in the classroom in diverse ways could help to ensure their active participation and use of ICT tools in practical lessons.

Many people believe that males become motivated and succeed in the use of ICT tools more than females. This idea is confirmed in the statement below:

It was found that males seemed to be gaining more in certain cases, but females were not being disadvantaged. Passey (2004) suggest that ICT helps males move from a 'burst' pattern of working to a more persistent one - in other words, ICT can help males work more like females.

However, the researchers of this study are of the view that motivating and encouraging female students will help to empower them in the use of ICT tools.

According to a study by Volman (2005), teachers believed that boys were motivated more by higher levels of access to ICT, and where ICT activities were competitive in nature and short in duration. A few teachers reported that girls need more support than boys in their use of ICT. This may however be due to the different approaches girls and boys take to working with ICT, rather than a lack of skills - a study from the

Netherlands found that girls preferred to have an explanation before starting ICT activities, whereas boys would rather try things out for themselves.

Lier (1996) argues that 'IRF's (initiation response feedback) strict regulation and the asymmetry of the teacherstudent relationship embedded in its structure decreases students' motivation to contribute to classroom interaction'. This is to emphasize that a good student-teacher relationship must prevail in the classroom setting to ensure students' full participation in activities. To be able to achieve this, a number of strategies must be employed to motivate as well as giving the students free will to operate in the classroom with little or no restriction.

In contrast with the literature reviewed on the above-mentioned subject, the researchers refused to address certain crucial issues notably gender differences in access and use, gendered digital divide, tertiary education and ICT, gender symbolism and feminist stand point theory.

By comparison, most of the literature on gender and ICT consider access by women to ICT. This includes concerns about infrastructure, training, local content and women in rural or underserved areas. Yet, to be in a position to benefit from the era of ICT, such as computer supported learning, both access and use of ICT are vital (Agbonlahor, 2005; Tinio, 2008). The problem however is the gendered digital divide (DD) as manifest in observed gender disparities in access as well as in use (Morahan-Martin 2000; Etta \& Elder, 2005).

The gender and technology approach lead directly to the issue of meanings and values as they are created, defined and eventually attached to the use of ICT.

\subsection{Relationship between Practical Learning and Students' Performance}

According to Edge (2006), "findings send out a clear message. If they had their school days again, adults would prefer to have more learning by doing and less learning in the classroom or from a textbook. So why isn't this happening?" This statement indicates that experienced people who are in the work field even regret for not having the opportunity to learning through practicals. Empowering young people at the Junior High School level and beyond to acquire manipulative skills will be of greater help.

Edge (2006) further placed much emphasis on practical learning which is seen in this statement "Practical learning is regarded as of value to all and lacks the baggage and history of vocational qualifications and initiatives. We 
think it is the best way of equipping our young people with the practical skills all seem to agree are needed". The paper continued by saying; "it's an interesting point; perhaps vocational learning as a term has become too closely associated with government inspired initiatives whereas practical learning encapsulates active learning at its purest from the project table in the primary classroom to the workshop in the college "....

This suggests that even those who might think to favour a more traditional form of education (theory-based learning) believe that schools and colleges should be adopting a more practical approach to learning. "This is not a cry" according to Edge 'for the introduction of vocational options in schools which channel young people into specific careers, rather it's a plea for a more practical approach to learning'. Edge again expressed the view that "at least many in the teaching profession favour practical learning and not just for the low achievers either".

The researchers of this study, after careful analysis of the view of Edge on practical learning, is optimistic that helping students at all levels to acquire skills in manipulating ICT tools will contribute tremendously to students' performance as well as the national economy.

Conner (2007) declared that "the way we learn technology must change, because the techniques needed to stay ahead in the information age will, most likely, not change as quickly as the technologies that sustain us". Allen (1974) commented that "the world of work is continually changing and it is the task of teachers in vocational education to encourage originality, initiative and thinking ability to cope with the changes". These two researchers saw the rapid changes in our world of work as a result of technology and therefore suggested to classroom teachers to change their strategies to help learners acquire the needed skills to meet the challenges ahead of them.

Distributed practices help in the encoding process to long-term memory by providing multiple rehearsal opportunities for the working memory and allowing students to identify areas where improvement is needed (Clark \& Mayer, 2003). Shin (2004) also added; "practice items are used to activate retrieval and reinforce memory. It provides learners opportunity to turn information into knowledge and skills and commit them to the long-term memory". These researchers actually confirmed the fact that learning through practical activities will contribute immensely to one's academic performance.

Teachers and educational authorities must provide enough room for students to practise what is taught. In the case of science and technological subjects such as ICT, Science, Agricultural Science, Technical Skills, etc. lessons should be delivered at the laboratories and workshops where students can experiment with equipment.

Sarfo (2009) discussed the effectiveness of practice as follows:

How well one improves with practice depends on several factors, such as the frequency it is engaged in. Generally, the more one practices, the faster one improves. If a student does not practice often enough, reinforcement fades, and he or she is likely to forget what was learned. Therefore, practice is often scheduled, to ensure enough of it is performed to reach one's training objectives. How much practice is required depends upon the nature of the activity, and upon each individual. Some people improve on a particular activity faster than others.

Given that practice is merely the reinforcement of actions that serves to generate an outcome or outcomes, it is believed that by improving the type of practice you do, you can in turn generate results at a faster rate.

The above literature informs that students need more practice to master concepts. Reinforcement is likely to bring about remembrance and perfection. The researchers of this study therefore saw the need to involve female students in practical activities as a means of building their capacity in the use of ICT tools.

Sarfo (2009) further discussed the five key processes that make for efficient practice, identified by Roberto Moretti. These are:

- Identification - building an awareness of what you are practising to ensure you know how to do it perfectly.

- Isolation - the selection and focusing on something that is the proper size for one's focus to process and execute with a high degree of perfection.

- Reinforcement - the action of consistently and continuously repeating the above-selected action so it becomes autonomous.

- Integration - the practising of interrelated actions either one after each other or together to construct and train in more complex actions or sequences of actions.

- Escalation - consistently selecting new practice material congruent with one's goals in skill acquisition as previous material is mastered.

On the contrary, Hu and Kuh (2001) define engagement in practical activity as "the quality of effort students themselves devote to educationally purposeful activities that contribute directly to desired outcomes" which the above reviewed literature underestimated it. By way of contrast, others have defined engagement as "the process whereby institutions and sector bodies make deliberate attempts to involve and empower students in the process of shaping the learning experience" (HEFCE, 2008). Combining these two perspectives, Kuh (2009) has defined student engagement as "the time and effort students devote to activities that are empirically linked to desired outcomes of college and what institutions do to induce students to participate in these activities".

To conclude, the literature reviewed on what motivation can do to sustain female students' participation in practical lessons of ICT and the relationship between practical learning and students' performance must be used as guide by teachers and all stakeholders in education to assist learners to develop interest as well as fully participate in classroom practical activities. The notion that "vocational education or subject is meant for the academically weak students" could be wiped away from the minds of learners.

Female students who always feel isolated and humiliated when it comes to the use of technological equipment, must be encouraged and motivated to feel comfortable in using ICT tools. As implication of behavioristic theory of learning, teachers must encourage learners' participation (Skinner, 1954). 


\section{Methodology}

\subsection{Introduction}

This action research aimed at employing strategies to ensure female students' involvement and use of ICT tools in ICT practical/activity lessons in St. Joseph's and Berekum Colleges of Education in the BrongAhafo. Accordingly, Leedy (1993) stated that a method is a way of accomplishing an end result. A research methodology, therefore, refers to a set of methods, systems and procedures used in a particular research to achieve stated objectives. Additionally, the word method is coined from two Greek words: 'meth' and 'odos'. A method is therefore, following after the way someone found to be effective in solving a problem or reaching an objective or getting a job done. The meth means 'after' and 'odos' means 'way'. Thus, if the data is verbal, the methodology is qualitative; if the data is numerical, the methodology is quantitative hence this study employed a quantitative methodology.

This section of the study is paramount hence it is liable to affect the results and conclusions of the study. It considers the methodology and research design employed for the study.

\subsection{Research Design}

According to Grandhi (2004), "a research design is the tentative outline of a proposed research work". Kerlinger (1986) defines research design as "a plan structure and strategy of investigation so convinced as to obtain answers to research questions or problems". Similarly, a research design is a procedural plan that is adopted by a researcher to answer questions in a valid way, as a provisional outline of this action research, the researchers employed about six (6) strategies to determine the appropriate research design.

The action research/case study is mainly descriptive since it involves investigating, recording, analyzing and interpreting data.

According to Gerber (2009), "the aim of descriptive research is to verify formulated hypotheses that refer to the present situation in order to elucidate it". This method seeks to describe the phenomenal change that will be manifested when female students are motivated and encouraged to fully participate and use ICT tools in ICT.

\subsection{Research Population}

A research population is a group of individuals, persons, objects, or items from which samples are taken for measurement (Mugo, 2009). In this regard, the present researchers considered the teaching and learning situation in the schools which called for two categories of people who were directly involved. Students and teachers of St. Joseph's and Berekum Colleges of Education were therefore captured as the main population for the study. The choice of this population became necessary since it was hoped to provide the researchers with relevant and immediate data needed for the analysis.

\subsection{Sample and Sampling Procedure}

According to Grandhi (2004) "a complete coverage of the units of the universe selected for research, is not possible. Instead of complete coverage, selected units are studied". Lunsford and Lunsford (1995, p55), also defined sample as "a small subset of the population that has been chosen to be studied". Lunsford and Lunsford further cautioned that "the sample should represent the population and have sufficient size ....". Best and Kahn (1989) have observed that the primary aim of research is to discover principles that have universal application.

In this regard, the researchers saw that considering the entire population would not help; instead part of the population would be sampled to ensure reliability and validity of data collection. The sample for the study was made up of one hundred and twenty (120) female students who were in the said Colleges of Education level two hundred (200), and forty (40) teachers.

The simple random sampling method was used to select the sample. The said sample is probability in nature in which each member of the population had a known and equal chance of being chosen in the sample. The method helped the researchers to identify and enumerate the finite population. To avoid selection bias, it is important to guarantee that each of the candidates for inclusion in the study has an equal opportunity for selection (Lunsford \& Lunsford, 1995).

Stratified sampling technique was also adopted alongside the random sampling since the study concerned the inclusion of gender group (female students) in ICT. According to Lunsford and Lunsford (1995), stratified sampling is "a method by which subjects are grouped according to strata such as age, gender or diagnosis. Using this method, subgroups of interest could be defined and ... sampled for each group".The said subgroup included seventy five percent (75\%) female students and twenty five percent (25\%) teachers who were used for the study. 


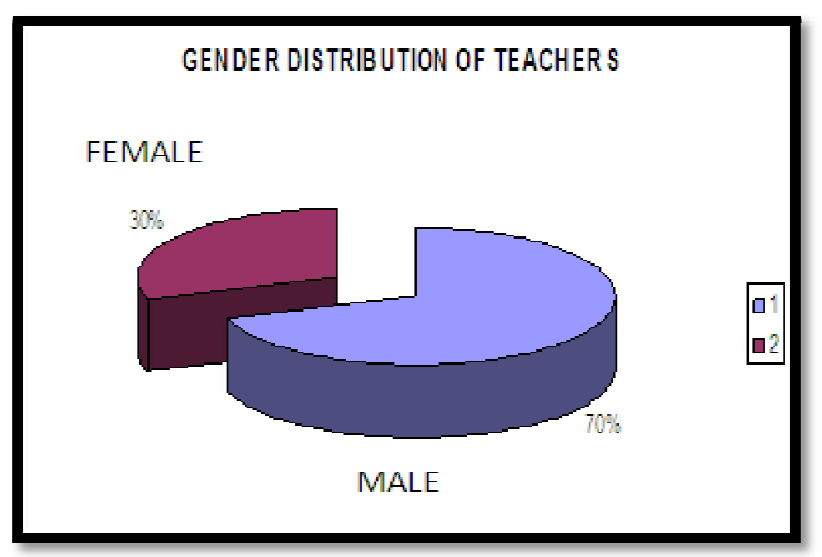

Figure 1: Gender Distribution of Teachers

\subsection{Instrumentation}

Research techniques refer to the methods for gathering reliable information to answer a question or support an experimental hypothesis (Okai, 2009). In view of this, the researchers of this study employed questionnaire technique to gather valid and reliable data in aid of rectifying the situation at hand. It must be emphasized here that gooddata is directly related to the questions; that is, they provide direct answers (Padak\&Padak, 2009).

According to Cohen, Manion and Morrison (2003), questionnaires can provide a structured and straightforward analysis of information. Moreover, questionnaires are relatively more economical than other approaches in terms of time and money and they can be convenient for respondents as they can complete them in their own time.

Questionnaire is usually more superficial than the interview. It is usually used in group work. The questionnaire is especially useful to obtain information about reasonably big groups. Questionnaire is usually characterized by relatively low cost, ease of interpreting information, and likelihood of answering each question.

\subsection{Data Collection Procedure}

The present researchers therefore sat down to carefully plan, design and administer one hundred and sixty (160) questionnaires to respondents (female students and teachers) to obtain information on the topic under discussion. These questionnaires were presented to the respondents during the data collection stage of the study. The items in the questionnaires were written in clear language to enable respondents understand and answer the questions objectively as possible. The choice of the questionnaire technique for the study was that many respondents could be reached within a short period of time. Respondents were expected to answer every item in the questionnaire. It also required little time of respondents. Some examples of sample items on the questionnaire included 'I am regular at ICT practical lessons', 'I feel happy and satisfied in ICT class', 'Practice makes man perfect', etc.

In addition, the respondents were given little opportunity to express their views as they were restricted to the questions and their corresponding answers. The main items contained in the questionnaire included how motivation can add value to female students' participation in ICT practical lessons; what teachers can do to develop female students' interest in ICT lessons and finally relationship between practical learning and students' performance.

\subsection{Intervention Design and Implementation}

This aspect of the study presents the actual measures were taken to alleviate the problem understudy. To intervene means "to become involved, intentionally, in a difficult situation in order to improve it or prevent it from getting worse". The researchers, after considering existing literature on the problem, came out with six (6) interventional strategies and their implementation which contributed to overcoming the challenges.

\subsection{Intervention Design}

Classroom research/ Case study focuses on identifying or evaluating the "method in our madness" as it affects our students' learning. As classroom teacher who has been teaching ICT at St. Joseph's College of Education since 2009 academic year, and attending certain academic programs in Berekum College of Education as well, a number of challenges that affect female students' learning and academic performance have been observed. The involvement and improvement in the use of technological equipment (ICT tools) among female students has become unease. The researchers of this study observed similar situation even among his university female counterparts during the period of study at the university.

Encouraging females' participation and improvement in practical lessons in ICT through motivation and attractive techniques was hoped to alleviate the fear and nervousness and equip them with the skills of using modern technology. To do this, the researchers proposed the following interventional designs and mechanisms to effect a change in female students' attitude towards practical lessons in ICT.

- Motivational techniques

- Good teacher-student relationship

- A talk on career opportunities in ICT

- Applying a variety of teaching methods

- Provision of guidance and counselling 


\section{- Maintaining good attitude of students and teachers towards ICT}

\subsection{Intervention Implementation}

The following describe how the intervention designs enumerated above were implemented in solving the problem.

\subsection{Good Teacher-Student Relationship}

In order to enhance friendly and free communication atmosphere for effective teaching and learning, the researchers managed to create good rapport with his students. Female students who had difficulties in ICT one way or the other felt free to approach the teacher for assistance. Interestingly, most of the female students confronted the researchers with their computer problems in the house while others sought for computer programs. In doing this, the researchers were very cautious in order not to be biased in such classroom relationships since it was aimed at improving performance and not mere social satisfaction.

\subsection{Applying a Variety of Instructional Methods}

According to Sarfo (2007), instructional strategy is the teacher's approach to using information, selecting resources, and defining the roles of students. In view of this literature, the researchers used varied teaching methods in the presentation of ICT lessons both in the computer laboratory and classroom. The researchers used discussion and demonstration methods, relevant teaching and learning materials, and further activity and practice to enhance students' understanding of the concepts. The researchers put students into small groups to work on activities, problems and exercises. The use of small groups helped the female students to share, participate and perform better in the subject. Again, the researchers used interactive participatory and learner-centered methods such as activity, questions and answers to create an active learning environment as emphasized by Needham and Hill $(1987$, p8) that "... learning is an active, not a passive process". A lot of exercises were given and marked instantly and the results discussed for improvement of performance.

\subsection{A Talk on Career Opportunities in ICT}

The researchers were aware that most students did not have any idea on career opportunities in ICT. Casually, when students were asked to mention some ICT career opportunities known to them, their responses were only Internet café operator and typist. The researchers upon consultation with school authorities organized a talk on

career opportunities in ICT. Resource personnel including renowned ICT gurus, old students and some ICT professionals were invited to help female students know why they needed to take ICT seriously. Colleges of Education online registration for admissions and semester examinations, WAEC online registration for examination and result checker, workers particularly females in the banks and other industries were used as examples to help female students appreciate the study of ICT. According to Brickman (2008), "the basic principle of career counselling and guidance is that a person is better equipped to make occupational plans after determining his or her own characteristics, examining the requirements of various occupations, and matching the two sets of facts with the aid of a skilled counselor".

\subsection{Provision of Guidance and Counselling}

According to Assoah (2008), some objectives of guidance and counselling for teachers and students are "to understand better the individuality of each student for whom they are responsible and to develop learning or study skills and values", respectively. The researchers, having observed that guidance and counselling section in the schools, which was endowed with trained and experienced personnel, could be useful in dealing with the problem at stake. The guidance and counselling coordinators were invited from time to time to ensure proper guidance for female students in studying ICT.

\subsection{Maintaining Good Attitude of Teachers and Students towards ICT in the Schools}

The Adentwi's quotation on role model states, "set it down to thyself, as well to create good precedence as to follow them" (Bacon, 1561 - 1626 in Adentwi, 2009). The researchers considered the need to take advantage of teachers' fundamental role as role model to promote positive attitude towards the study of ICT. In doing this, the researchers maintained good rapport between the teachers in the school. Teachers who used to show interest in learning computing were assisted to do so. The computer laboratory was also opened to all teachers who had the desire to use computer. By and large, all these female students got to know that ICT was very important since almost all teachers were willing to learn and use the computer. Teachers were advised during staff meetings to release students as soon as possible when it was time for ICT lessons. After implementing the interventions, female students' attitude towards ICT practical activities was improved tremendously. In general, the interventions employed in this research have had a great impact on female students' participation and improvement in ICT practical activities.

\subsection{Data Analysis}

Analysis according to Adentwi (2009) is "the examination of something in detail in order to understand it better or draw conclusions from it".

Data analysis involves examination of the data in the order in which your questions have been answered. If you have asked more than one question, you will want to sort the data according to the question. And you may want to discard (or at least set aside) data that do not directly relate to the questions you have posed. 
In an effort to make the presentation of the findings comprehensive and readable, the collected data were organized into frequency distribution tables for easy interpretation and analysis of results. Tables were used because they could easily be generated using tools like Ms Excel or statistical package for social sciences (SPSS) and they are also easily understood. This helped the researchers to make meaningful conclusions for the study. Specifically, the statistical test employed in this study was statistical package for social sciences (SPSS) for the interpretation and analysis of the results obtained.

\section{Data Analysis and Results}

\subsection{Introduction}

This section focuses on the presentation and analysis of data gathered from the field.

\subsection{Relationship between Practical Learning and Students' Performance}

When asked about the frequency students practice ICT, 38 (i.e. 31.7\%) of them indicated daily, 41 (i.e. 34.2\%) of them as well indicated weekly. 27 (i.e. $22.5 \%$ ) of the respondents said monthly while 14 (i.e. 11.7\%) of them also indicated annually.

As shown from table 1, more students devote time to persistent practice of ICT.

The significance of this finding indicates students believed that being committed and persistent with the allotted frequency would go a long way to enhance their practical based skills.

\begin{tabular}{|c|c|c|}
\hline Responses & Frequency & Percentage \\
\hline Daily & 38 & 31.7 \\
Weekly & 41 & 34.2 \\
Monthly & 27 & 22.5 \\
Annually & 14 & 11.7 \\
\hline Total & 120 & 100.0 \\
\hline
\end{tabular}

Table 1: Frequency Students Practice ICT

Source: Field Work July, 2018 (SPSS V16.0)

Students were asked the amount of time they get for practice during ICT lessons. Their responses are shown in table 4.4.2. 39 (i.e. $32.5 \%$ ) of them responded two hours, 35 (i.e. 29.2\%) of them indicated one and half hours, 34 (i.e. $28.3 \%$ ) of them said one hour while 12 (i.e. $10 \%$ ) of the respondents indicated thirty minutes.

As reflected in table 2, there is sufficient time for students' practice during ICT practical lessons. The relevance of this finding shows students appreciated the fact that the allotted time for their practice is indeed enough and has added value to their understanding.

\begin{tabular}{|c|c|c|}
\hline Responses & Frequency & Percentage \\
\hline Two hours & 39 & 32.5 \\
One and half hours & 35 & 29.2 \\
One hour & 34 & 28.3 \\
Thirty minutes & 12 & 10.0 \\
\hline Total & 120 & 100.0 \\
\hline
\end{tabular}

Table 2: Time Limit Students Practice ICT during Practical Lessons Source: Field Work July, 2018 (SPSS V16.0)

Table 3 shows responses of students when they were asked whether practice makes someone perfect. Their responses are shown in table 4.4.3. 85 (i.e. 70.8\%) of them indicated very true while 35 (i.e. 29.2\%) of the respondents said true. It is clear from the table that practice undoubtedly makes one perfect. The significance of this finding indicates students believed that constant practice has enabled them gain mastery and understanding of concepts taught in ICT practical lessons.

\begin{tabular}{|c|c|c|}
\hline Responses & Frequency & Percentage \\
\hline Very true & 85 & 70.8 \\
True & 35 & 29.2 \\
\hline Total & 120 & 100.0 \\
\hline \multicolumn{2}{|c|}{ Table 3: Students' Perfection through Practice } \\
\multicolumn{2}{|c|}{ Source: Field Work July, 2018 (SPSS V16.0) }
\end{tabular}

When asked whether well organised practical-based lessons can add value to students' success in exam, 76 (i.e. 63.3\%) of the respondents indicated very true while 44 (i.e. 36. 7\%) of them indicated true.

As reflected in table 4, well organised practical-based lessons can have a positive result on students' success in exam. The relevance of this finding shows students accepted the fact that if they are taught to learn practically, their wish to pass examination is stimulated. 


\begin{tabular}{|c|c|c|}
\hline Responses & Frequency & Percentage \\
\hline Very true & 76 & 63.3 \\
True & 44 & 36.7 \\
\hline Total & 120 & 100.0 \\
\hline
\end{tabular}

Table 4: Effects of Well Organised Practical Lessons on Students' Success in Exam

Source: Field Work July, 2013 (SPSS V16.0)

When asked whether systematic and well delivered practical demonstrations could be linked to students' performance, 78 (i.e. 65\%) of the respondents indicated vey true while 41 (i.e. 34.2\%) of them said true. However, 1 $(0.8 \%)$ of them indicated not true.

As reflected in table 5, systematic and well delivered practical demonstrations are pivotal to students' performance. The relevance of this finding shows students accepted the fact that using ICT tools appropriately and systematically could encourage a more student-oriented approach thereby enhancing their understanding as well their performance.

\begin{tabular}{|c|c|c|}
\hline Responses & Frequency & Percentage \\
\hline Very true & 78 & 65.0 \\
True & 41 & 34.2 \\
Not true & 1 & .8 \\
\hline Total & 120 & 100.0 \\
\hline
\end{tabular}

Table 5: Effects of Systematic and Well Delivered Lessons on Students' Performance

Source: Field work July, 2018 (SPSS v16.0)

\section{Conclusion}

\subsection{Relationship between Practical Learning and Students' Performance}

Students were asked about the frequency they practise ICT during practical lessons. Their responses are shown in table 4.4.1. Thirty-one-point seven percent indicated daily, thirty-four-point two percent as well indicated weekly. Twentytwo-point five percent said monthly while eleven-point seven percent also indicated annually. Majority of the students reported that the allotted frequency for their practice in ICT is enough to a very large extent. They believed that being committed and persistent with the allotted frequency would go a long way to enhance their practical based skills. Greater percent of the students said they are comfortable in the following to a large extent: daily practice is the most excellent $31.7 \%$, weekly is more exellent- $34.2 \%$, monthly is good- $22.5 \%$ and lastly with a handful of them saying annually is somehow ok-11.7\%

The data in table 4.4.1 indicate clearly that the frequency students have at their disposal for practice has improved tremendously.

To investigate this same question, students were asked to indicate the time frame they get for practice in ICT lessons. They were to choose one of the following options:

'two hours', 'one and half hours', 'one hour' and 'thirty minutes'. Greater percent of them accepted that they were comfortable with two hours and the next higher percentages respectively openly indicated one and half hours and one hour. However, only a handful of them reported thirty minutes and this clearly does not have any material effect on the reports of the majority. Thus, the allotted time for their practice is indeed enough and has added value to their understanding. The results of this current study have undoubtedly enhanced students' practical skills in line with the allotted time.

Again, respondents were asked whether practice has the tendency to make them perfect. They were to make a choice from one the following: 'very true', 'true' and 'not true'. Substantial percentage of them reported very true and the rest reported true. Nonetheless, none of the respondents reported otherwise. Clearly, hundred percent of them argued that no one could attain perfection on the silver platter and also added that winners never quit, neither do quitters win. This is consistent therefore with the Chinese proverb which reads "I hear and I forget. I see and I remember. I do and I understand". Practise or practice is the "act of rehearsing behaviour over and over, or engaging in an activity again and again, for the purpose of improving or mastering it, as in the phrase "practice makes perfect". It is a method of learning and of acquiring experience" (Sarfo, 2009).

The data of this current study lend credence to the fact that perfection has a direct correlation with constant practice.

To investigate this same question, respondents were asked whether well organised practical based- lessons could add value to students' success in exam. Majority of them by popular acclamation reported very true while the remaining appreciable percentage confirmed true. Accordingly, Nulden (1998) says if we teach the students what to learn practically, we stimulate their wish to pass the examination. If we learn how we teach, we can stimulate the wish to ask questions, to learn more, the knowledge comes automatic. Greer (2001) also argues that students take an approach to their learning in relation to what is expected of them which has a relation on students' performance. A confirmation is being made here to indicate consistency with the reviewed literature.

The findings from the table indicate that well organised practical based-lessons can have a material effect on students' success in examination.

To address the said question, respondents were again asked whether well delivered and understood lessons could be linked to systematic and good practical demonstrations. 
Respondents were to make a choice from one of the following: 'very true of me', 'true of me' and 'not true of me. Greater percent reported very true of me and the next appreciable percent reported true of me. However, only one person reported otherwise. This is therefore confirmed by the researchers below: The instructor who uses ICT in the lessons is perceived to be the essential factor in the improvement process (Veen, 1995). The teacher plays a critical role in organising and managing the learning environment as well as acting as a specialist who is guiding pupils (Smeets\&Mooij, 2000). The learner usually decides what activities have to be carried out in the learning process (Jonassen, 1993). The confirmation has been indicated to prove that the findings have not deviated from the information in the reviewed literature.

Gallagher (1995) also stated that using the computer made their work more attention-grabbing and effective. In fact, using ICT can encourage a more student-oriented approach thereby enhancing their understanding. The data from that table confirm that learners' understanding can be sustained and polished by employing systematic and good practical demonstration. The last confirmation has to do with consistency of data as reviewed in the literature.

\section{References}

i. Allen, D. (ed) (1974). Instruction. In Malvin L. B.The Philosophy for Quality Vocational Education Programs.Washington, DC: American Vocational Association

ii. Adentwi, K.I. (2009). Psychology of Human Development. Kumasi: Biraa Press. pp. 22-40

iii. Archer, F. (2003).Measurement and evaluation in education.Kumasi: PAKS Publications, pp. 13

iv. Asiedu-Addo, S. (2008).Encourage females to study technical subjects. Junior Graphic.pp. 3.

v. Assoah, S. K. (2008). Guidance \&counselling in education. Kumasi: Biraa Press. pp. 10

vi. Abdulla, Y. \&Twizell, EH. (2008). Higher Education in the 21st Century:Issues and Challenges.London, Taylor \& Francis Group, UK.

vii. Bacon, F. (2008).Set it down to thyself, as well to create good precedents as to follow them. In Microsoft Encarta Student 2009 [DVD].Washington Redmond: Microsoft Corporation

viii. Becta (2008).How do boys and girls differ in their use of ICT? - Research report Retrieved July 18 2018, from http:/ / partners.becta.org.uk/ uploaddir/

ix. Ben-Jacob, M. G. (2005). Integrating computer ethics across the curriculum:

x. A case study, Educational Technology \& Society, pp. 198-204.

xi. Berliner, D. C. (2008).Educational psychology. In Microsoft Encarta Student 2009 [DVD]. Redmond, WA: Microsoft Corporation.

xii. Brause, R. S. \&Mayher, J. S. (Ed.) (1994).Search and re-search: what the inquiring teacher needs to know. United Kingdom: The Falmer Press, Rankine Road Basingstoke, Hampsphire RG24 OPR87

xiii. Broussard, S. C., \& Garrison, M. E. B. (2004).The relationship between classroom motivation and academic achievement in elementary school-aged children. Family and Consumer Sciences Research Journal, 33(2), 106120.

xiv. Brickman, W. W. (2008). Vocational education. In Microsoft Student 2009 [DVD]. Redmond, WA: Microsoft Corporation.

xv. Brundtl and, G. H. (2002). World Health Organization (WHO) Director-general's executive statement on gender policy: Integrating Gender Perspectives I the Work of WHO.

xvi. Clark, R.C \& Mayer, R.E. (2003). E-Learning and the science of Instruction: proven guidelines for consumers and designer's multimedia learning. San Francisco: Pfeiffer

xvii. Cradler, J., McNabb, M., Freeman, M. \& Burchett, R. (2002). How does technology influence student learning. Retrieved March 15, 2018, available at: http:/ / caret.iste.org/ caretadmin/ news documents/ StudentLearning.pdf.

xviii. Conner, M. L. (2007). A primer on educational psychology. Retrieved February 18,

xix. 2009, available at: http:// agelesslearner.com

xx. Deci, E. L. \& Ryan, R. M. (1985). Intrinsic motivation and self-determination in Human behavior. New York: Plenum. ISBN 0-30-642022-8.

xxi. Derbyshire, H. (2003). Gender issues in the use of computers in education in Africa,

xxii. DFID: 73

xxiii. Deci, E. L. (1971). Effects of externally mediated rewards on intrinsic motivation Journal of Personality and Social Psychology, 18, 105-115.

xxiv. Eisenberg, N. (2010). Self-regulation and school readiness. Early Education and Development, 21(5), 681-698.

xxv. Eccles, J., Midgley, C., and Wigfield, A., (1993). Development during adolescence: The impact of stageenvironment fit on young adolescents' experiences in schools and families. American Psychologist, 48, 90-101.

xxvi. Eisenberger, R., \& Cameron, J. (1996). Detrimental effects of reward: Reality or myth? American Psychologist, 51, 1153-1166.

xxvii. Entwistle, N. J (general editor) (1990). Handbook of educational ideas and practices. London and New York: Routledge pp. 144.88

xxviii. Fuglestad, A. B. (2005). Students' use of ict tools - choices and reasons. In Chick, H.

xxix. L. \& Vincent, J. L. (eds.) Proceedings of the 29th conference of the international group for the psychology of mathematics education. Melbourne: PME, AgderUniversity College Vol. 3, pp. 1-8.

xxx. Guay, F. (2010). Intrinsic, identified, and controlled types of motivation for school subjects in young elementary school children. British Journal of Educational Psychology, 80(4), 711-735.

xxxi. Gerber, R. (2009). Research skills: Centre for Teaching, Learning and Media. Nelson 
xxxii. Mandela Metropolitan University. Retrieved March 15, 2018 from http:// www.petech.ac.za/ robert/ research.html

xxxiii. Grandhi, N. (2004). Introduction to research methodology, Block 1. National Open University, School of Social Sciences.

xxxiv. Grubb, W.N., Lazerson, M. (2005). Vocationalism in Higher Education: The Triumph of the Education Gospel.

xxxv. Garrison, D.R \& Anderson, T. (2003). E-learning in the 21sth century- A framework for research and practice. New York and London, Routledgefalmer.

xxxvi. Greer, L. (2001). Does changing of Method of Assessment of a Module Improve the

xxxvii. Performance of a Student.Assessment and Evaluation in Higher Education.

xxxviii. 26(2)

xxxix. Hafkin, N. \& Taggart, N. (2001). Gender, information technology, and developing countries: An Analytic Study. Washington: USAID Retrieved April 17, 2009 from http:/ / www.usaid.gov/ wid/ pubs/ it01.htm

xl. Hyde, J. S., \& Kling, K. C. (2001). Women, motivation, and achievement. In

xli. Psychology of Women Quarterly, 25, pp. 364-378

xlii. Haynie, W.J. III (2003) Gender issues in technology education: A Quasi-

xliii. Ethnographic Interview Approach.In Journal of Technology Education

xliv. Vol. 15 No. 1, Fall2003

xlv. Hornung-Prahauserm, R. M. V, Eliane S. (2005). Inclusion of females in ICT - A lifelong learning challenge for changeagents: Benefits of innovative e-learning tools and training methods. Retrieved March 10, 2018, from http:/ / www.salzburgresearch.at/ research gfx/ eden proict 2005.pdf

xlvi. Harter, S. (1981). A new self-report scale of intrinsic versus extrinsic orientation in the classroom: Motivational and informational components. Developmental Psychology, 17, 300-312.

xlvii. Harter, S. (1992). The relationship between perceived competence, affect, and motivational orientation within the classroom: Processes and patterns of change. In A. K.

xlviii. Johnson, K. (2003). Telecentres and the gender dimension: an examination of how engenderedtele centres are diffused in Africa. Georgetown: Unpublished MSc thesis, Georgetown University.

xlix. KNUST (2009). Admission brochures for 2009/ 2010 academic year. Kumasi: Kwame

l. Nkrumah University of Science and Technology. Retrieved February 07, 2009, from http:/ / admissions.knust.edu.gh

li. Leedy, P. D. (1985). Practical research: planning and design. (3rded.). New York: McMillan Publishing Co.

lii. Lunsford, T. R. \& Lunsford, B. R. (1995). Research forum--the research sample, part sampling, In Journal of Orthotists and Prosthetists, America Academy of Orthotists and Prosthetists. Retrieved May 13, 2018, from http:/ / www.oandp.org/jpo/ library/ index/ 1995 03.asp. pp. 105-112

liii. Leuven, Z. (2004). Reading Behaviour in the digital environment: changes in Reading behaviour over the last 10 years. J. Doc, 61 (6): 700-12

liv. Macueve, G., Mandlate, J., Ginger, L., Gaster, P. \&Macome, E. (2009). Women's use of information and communication technologies in Mozambique: a tool for empowerment? pp. 22 Martin, A. \& Marsh, H. (2005). Motivation of girls' research article. In Australian Journal of Education (2009) Motivating boys and motivating girls: does teacher gender really makes a difference?.

lv. Maslow, A. H. (1943). A theory of human motivation. Psychological Review, 50, pp. 370-396

lvi. Millar, J. \&Jagger, N. (2001). Women in ITEC Courses and Careers. Brighton, UK: University of Sussex. pp. 40-50. Retrieved March 10, 2018, from http:/ / www.womenandequalityunit.gov.uk/ research/pubn_2001.html

lvii. Mitter, S. (2007). Globalisation and ICT: Employment Opportunities for Women Part III.

lviii. Mugo, F. W. (2009). Sampling in research. London: Chapman \& Hall. pp. 169-184.

lix. Maslow, A. (1954). Motivation and personality. New York: Harper.

lx. Margolis, J. \& Fisher, A. (2002). Unlocking the clubhouse: Women in Computing MT Press

lxi. Nobel, C. (2007). Back to school: getting girls into IT. In InfoWorld.29 January, Retrieved March 10, 2018, from www.infoworld.com/article/ 07/ 01/ 29 / 05FEwomentechteen 1.html

lxii. Nulden, U. (1998). The Excon Project: Advocating Continuous Examination. The SIGSCE Technical symposium on Computer Science Education, Atlanta, USA, ACM Press

lxiii. Needham, R \& Hill, P. (1987). Teaching strategies for developing understanding in science; Children's Learning in Science Project. Leeds: University of Leeds, LS2 9JT.

lxiv. OECD/ European Communities (2004). Career guidance: a handbook for policy makers. France Paris: OECD Publications, 2. Retrieved March 25, 2018 from http:// www.oecd.org/ dataoecd/ 53/ 53/ 34 060761.pdf

lxv. Omamo, S. A. (2009). Reflections on the mentoring experiences of ICT career women in Nairobi, Kenya: looking in the mirror. In The International Development Research Centre (IDRC). pp. 19 of 22

lxvi. Owusu-Banahene, N. O. (2007). Educational psychology: The science of learning. Kumasi: Narco Printing Works, KNUST, pp. 222-231.

lxvii. Padak, N. \&Padak, G. (2009).Research to practice: guidelines for planning action research projects. In Ohio Literacy Resource Center. Retrieved 15, 2009, from http:/ / literacy.kent.edu/ Oasis/ Pubs/ 0200-08.htm

lxviii. Pamela J. S. \& Stephenson, R. (2008).Giving and getting career advice: a guide for junior and senior faculty. Retrieved March 29, 2018, from http:/ / sitemaker.umich.edu / advance

lxix. Passey, D. (2004). The motivational effect of ICT on pupils - research report RR523. DfES. In Becta (2008) How do boys and girls differ in their use of ICT? Retrieved July 18, 2018, from http:/ / partners.becta.org.uk/ uploaddir/ downloads / page documents/ research/ gender_ict_briefing.pdf 
lxx. Payton, F., L. Kvasny, V. M. \&Amadi, A. (2007).Gendered perspectives on the digital divide IT education and workforce. Proceedings of the $9^{\text {th }}$ International Conference on Social Implications of Computers in Developing Countries, São Paulo.

lxxi. Pintrich, P. R., \&Schunk, D. (2002).Motivation in education: Theory, research and applications (2nd ed.). Upper Saddle River, NJ: Prentice-Hall.

lxxii. Robin, A. (1997). Policy and practice in primary education local initiative: National Agenda (2nd ed). London: Routledge, EC4P 4EE 11 New Fetter Lane.

lxxiii. Ryan, R. M., \&Deci, E. L. (2000).Self-determination theory and the facilitation intrinsic motivation, social development, and well-being. American

lxxiv. Psychologist, 55, 68-78.

lxxv. Rogers, C. (1963). The actualizing tendency in relation to "motives" and to consciousness. In M. R. Jones (Ed.), Nebraska symposium on motivation (Vol11, pp. 1-24). Lincoln, NE: University of Nebraska Press.

lxxvi. Skinner, B. F. (1953). Science and human behavior. New York: Macmillan.

lxxvii. Samman, T. (2008).Promoting ICT among young women in Europe. In Microsoft

lxxviii. Corporate Affairs. Retrieved March 29, 2018, from http:// www.buildaskill.com/ blog/ category/ editorials/ commentary Sarfo, F. K. (2007). Educational technology; instructional technology. Kumasi: Ospra Publishing Company Limited, pp. 118, 128.

lxxix. Sarfo, F.K. (2009). Practice (learning method).Kumasi: Ospra Publishing Company Limited, pp. 130, 152.

lxxx. Shackelford, R. (2006). Computing curricula 2005: The overview report, the association for computing machinery (ACM), the association for information systems (AIS), the computer society (IEEE-CS).Retrieved March 25, 2018 from http:/ / www.acm.org/ education/ curric vols/ CC2005- March06Final.pdf

lxxxi. Sharma, U. (2003). Women's empowerment through information technology, New Delhi: Authors' Press.92

lxxxii. Shin, H. K. (2004, October 1). Using technology to guide the learning of declarative knowledge. In ITE teachers' conference: Reflective practitioners in action. Singapore: institute of technical education

lxxxiii. Simons, J. A., Irwin, D. B. \&Drinnien, B. A. (1987).Psychology - the search for understanding. New York: West Publishing Company. Retrieved February 18, 2009, frhttp:/ / honolulu.hawaii.edu/ intranet/ committees/ FacDevCom/ guidebk/ teachtip/ maslow.htm

lxxxiv. Stephen, A. (2006). Communication technologies and women's empowerment. New Delhi: Rajat.

lxxxv. Ghana. Ministry of Education Science and Sports (2004).Teaching syllabus for information and communications technology (College of Education). Accra: Ministry of Education Science and Sports, pp. ii

lxxxvi. Van Lier, L. (1996). Interaction in the language curriculum: awareness, autonomy and authenticity. London: Longman.

lxxxvii. Ghana. WAEC (2008).Online registration, West African Examination Council. Retrieved March 29, 2018, from http:/ / www.waecdirect.org

lxxxviii. Weller, M. (2005).General principles of motivation. In Los Angeles Business Journal.

lxxxix. White, R. W. (1959). Motivation reconsidered: The concept of competence. Psychological Review, 66, 297-333.

xc. Zimmermann, L. \& Sprung, G. (n.d.) Technology is female: How girls can be motivated to learn programming and take up technical studies through adaptations of the curriculum, changes in didactics, and optimize interface design. Graz,AUSTRIA: AltePoststr. 149, 8020. Retrieved July18, 2018, from http:/ / icee2008hungary.net/ download/ fullp/ full_papers/ full_paper454.pdf 